\section{Non-Pedicled Buccal Fat Pad Grafts to Treatment for Class I and II Gingival Recessions: A Clinical Trial}

Tatiana Miranda Deliberador ${ }^{1}$, Claudia Tenório Trevisani², Carmen Lucia Mueller Storrer ${ }^{1}$, Felipe Rychuv Santos ${ }^{1}$, João César Zielak ${ }^{1}$, Celso Bernardo de Souza Filho ${ }^{3}$, Edson Alfredo ${ }^{1}$, Allan Fernando Giovanini ${ }^{1}$
'Graduate Program in Dentistry, Positivo University, Curitiba, PR, Brazil ${ }^{2}$ Private Pratice, Curitiba, PR, Brazil ${ }^{3}$ Professor, Positivo University, Curitiba, PR, Brazil

Correspondence: Tatiana Miranda Deliberador. Rua Professor Pedro Viriato Parigot de Sousa, 5300, Campo Comprido, 81280-330 Curitiba, PR, Brasil. Tel: +55-41-99976-4948. e-mail: tdeliberador@gmail.com
The aim of this study was to analyze the transplant efficiency of non-pedicled buccal fat pad graft (BFPG) for the treatment of Miller Class I or II gingival recessions (GRs) and to compare these results with those of subepithelial connective tissue graft (SCTG), which is considered the gold standard. Twelve patients with Miller Class I or II ( $\geq 2 \mathrm{~mm})$ bilateral recessions in maxillary premolars or canines were selected. Recessions were randomly assigned to receive SCTG or BFPG. The clinical parameters evaluated at baseline and at 1,3 , and 6 months postoperatively included gingival index, plaque index, probing depth, GR, clinical attachment level, width of keratinized tissue, thickness of keratinized tissue and gingival margin to the acrylic guide. None of the evaluated clinical parameters differed significantly between the groups. At all evaluated postoperative time-points, both groups exhibited statistically significant differences in GR and gingival margin to the acrylic guide compared to baseline. Six months after surgery, the mean percentages of root coverage were $67.5 \%$ and $87.5 \%$ in the BFPG and SCTG groups respectively. In both groups, complete root coverage was observed in 50\% of cases 6 months after surgery. The results presented herein indicate that the use of BFPG transplant has clinical similarities with SCTG and both may be considered as clinically successful methods for treating Miller Class I and II GRs.

\begin{abstract}
Key Words: adipose tissue, connective tissue, gingival recession, transplants, autogenous, split-mouth, case-comparison studies.
\end{abstract}

\section{Introduction}

Gingival recession (GR) is defined as apical positioning of the gingival margin in relation to the cemento-enamel junction (CEJ), and it results in root exposure, dentin hypersensitivity, esthetic impairment, root caries and non-carious cervical lesions. Poorly positioned teeth, traumatic brushing, and biofilm-derived inflammation are the main etiological factors associated with GR. Evidences show that surgical treatment for GR may reduce dentin hypersensitivity and cervical caries, increase the width of attached gingiva and improve esthetic harmony as a whole. In general, patients have shown a great deal of interest in root coverage, which has become a challenge for clinicians (1).

Different surgical approaches have been used to cover areas with GRs. Among them, the subepithelial connective tissue graft (SCTG) technique has achieved the best clinical results in the treatment of localized GRs (2). It is one of the most studied forms of treatment, as it is highly predictable in terms of exposed root coverage in Miller Class I and II recessions, for both the short and long term $(3,4)$.

The hard palate is one of the used donor sites in the connective tissue graft technique. In many cases, however, this procedure causes discomfort and postoperative pain, and it is associated with a risk of immediate and/or delayed hemorrhage. Therefore, in many cases patients are not willing to undergo this surgical procedure (5). Thus, other options have recently been described in the literature for the treatment of GRs $(6,7)$, such as the use of adipose tissue grafting. El Haddad et al. (6) introduced the root coverage technique, which utilizes a pedicled buccal fat pad graft (BFPG) derived from the patient's cheek, called "Bichat's Ball". In that case report, excellent clinical results were obtained during the treatment of a Miller Class IV recession. The authors considered this donor area less painful and less uncomfortable to the patient in comparison to the palate. In addition, it can be easily accessed. Kumari et al. (7) also used pedicled BFPG for root coverage of a maxillary first molar with Miller Class III GR. The authors reported that the cosmetic outcome was excellent in this case.

Recently, non-pedicled and pedicled BFPGs have been used in the oral reconstruction of 23 patients with different intraoral surgical defects in the palate, the maxilla, the gingiva and the cheek mucosa. Excellent clinical results were achieved (8). While the use of the buccal fat pad has been well documented in the literature, there are still no reports of the use of non-pedicled BFPG for the treatment of GRs. The aim of this study was to analyze the efficiency of non-pedicled buccal fat pad graft (BFPG) transplant for the treatment of Miller Class I or II gingival recessions 
(GRs) and to compare the results with those of subepithelial connective tissue graft (SCTG), which is considered the gold standard.

\section{Material and Methods}

\section{Study design and population}

Herein is reported a controlled randomized clinical trial with a split-mouth design. Twelve patients were selected, 8 women and 4 men, with a mean age $41 \pm 11.9$ years (range 21-65). They were informed of the risks and benefits of the clinical investigation, as well as the associated procedures and they provided written informed consent. The study was approved by the Ethics and Research Committee of Positivo University (application number 083/2010) and registered with Clinicaltrials.gov (identifier NCT02393053).

To satisfy the inclusion criteria, patients were required to be or have: (1) Miller Class I B or II GRs located bilaterally in the vestibular surface of upper premolars or canines $\geq 2$ $\mathrm{mm}$; (2) differences between the recessions on the right and the left sides of $\leq 3 \mathrm{~mm}$; (3) non-smokers; (4) non-pregnant; (5) systemically healthy; (6) periodontally healthy with no contraindications for periodontal surgery; (7) no use of any kind of medicine that could interfere with the health of gingival or periodontal tissue; (8) teeth with a probing depth (PD) of $<3 \mathrm{~mm}$ and without bleeding on probing; (9) teeth with no caries or restorations in the cervical region; and (10) not undergone any prior periodontal surgery in the relevant regions.

\section{Initial Therapy}

All patients underwent a basic periodontal treatment including scaling, root planning, tooth polishing and oral hygiene instruction. Additionally, all patients were included in a pre-treatment program to eliminate possible etiological factors related to GR. Patients were instructed to perform a non-traumatic brushing technique using a toothbrush with soft bristles. The surgical procedure was performed only in patients who had adequate plaque control.

\section{Clinical Parameters}

Thirty days after initial therapy, clinical parameters were recorded by a single calibrated operator with professional experience in periodontics, prior to the surgery (baseline), and at 1, 3, and 6 months postoperatively. The periodontal probe used was North Carolina (UNC-15, Hu-Friedy, Chicago, IL, USA). At baseline, an acrylic resin guide (AG) was made directly in the mouth of each patient and for each experimental tooth. A reference point (slot) was created in the most central vestibular portion of the $A G$ in order to obtain a fixed reproduction of the periodontal probe position, so that the measures of the clinical parameters could be standardized.
The clinical parameters evaluated were gingival index (GI) (9); plaque index (PI) (10); PD, measured from the gingival margin (GM) to the bottom of the gingival sulcus; $\mathrm{GR}$, measured from the CEJ to the $\mathrm{GM}$; clinical attachment level (CAL), measured from the CEJ to the bottom of the gingival sulcus; width of keratinized tissue (WKT), measured from the mucogingival junction (MGJ) to the GM; and the thickness of keratinized tissue (TKT), measured with the periodontal probe placed perpendicularly along the tooth axis in the most central portion of the keratinized tissue, between the GM and the MGJ. Under local anesthesia, slight pressure was applied to the probe, towards the adjacent hard tissue. A measurement (in $\mathrm{mm}$ ) was then recorded, and the last mean calculated referred to the $G M$ to the $A G$ $(G M-A G)$, measured from the GM up to the most coronal point of the AG. Six months after surgery, the percentage of root coverage was calculated by the following formula:

\section{Postoperative GR - Preoperative GR (baseline)} $\times 100 \%$

Preoperative GR (baseline)

\section{Surgical Procedures}

All surgical procedures were performed by the same operator, an experienced specialist in periodontics. In every patient, the GRs on each side were randomly assigned to receive either the control treatment (SCTG; group $\mathrm{C}$ ) or the tested treatment (BFPG; group T). The same operator performed both surgeries on the same day. Intra-oral antisepsis with $0.12 \%$ chlorhexidine digluconate was applied prior to all surgical procedures. The initially evaluated clinical parameters were $\mathrm{GI}$ and $\mathrm{PI}$, next PD, GR, CAL, WKT and GM-AG were evaluated with an AG.

\section{Preparation of the Recipient Site}

After local infiltration of anesthesia (mepivacaine hydrochloride $2 \%$ + epinephrine $1: 100,000$ ) at the bottom of the vestibule in the region of the maxillary canine or maxillary premolars, TKT was measured. An intrasulcular incision was then made from the distal side of the maxillary canine or the premolar, towards the patient's mesial side, with great care taken to ensure the preservation of the interdental papillae. Two divergent vertical releasing incisions were then made towards the bottom of the vestibule. A partial-thickness flap was then raised, releasing all muscle fibers so that the flap could be coronally loosened and slid. The roots were then gently debrided and flattened with Gracey curettes 5-6 (Hu-Friedy), and the area was rinsed with sterile saline solution to remove dentine debris. With an $A G$, the distance from the most coronal portion of the recipient site (CPRS) to the $A G$ (CPRS-AG) was measured. The flap had to be raised, so that the most coronal portion 
of bone tissue over the root of the AG could be measured. The standard surgical procedure was to start on the patient's right side regardless of the type of surgery being performed (group C or T). The preparation of the recipient site was conducted the same way for both groups.

\section{Preparation of the Donor Site}

Prior to obtaining connective tissue grafts, each patient was administered infiltration anesthetic into the hard palate, on the same side of the recipient site randomly assigned to receive SCTG. Removal of connective tissue was then performed by an L-shaped incision. Immediately after it was harvested, the graft was positioned into the recipient site at the CEJ level and fixed by a simple V-shaped compressive suturing with absorbable suture (Fig. 1A). After the graft was sutured with an $A G$, the most coronal portion of the graft to the AG (CPG-AG) was measured, as was the apico-coronal height of the graft (ACHG). Among the 12 patients in the current study, the height of the grafts ranged from 6.5 to $8.9 \mathrm{~mm}$. The flap was positioned coronally, in order to cover the connective tissue graft as a whole. Suspensory and simple sutures were made in

and molars at the intended BFPG recipient site. A horizontal incision measuring $1.5 \mathrm{~cm}$ was made at the bottom of the vestibule with a $n^{0} .15$ blade, in the region of the maxillary right and left first and second molars, depending on which side the surgery was being performed. A curved hemostat was used to reposition temporarily the muscles at the relevant location, in order to expose the adipose tissue (Fig. 2A). A $1.5 \times 1.5-\mathrm{cm}$ portion of adipose tissue was then removed with Goldman Fox scissors. The patient's cheek was then compressed, in order to promote the closure of the edges of the wound and joining the tissue. The donor site was immediately sutured with 4.0 silk thread (Ethicon; Johnson \& Johnson A.G., São Paulo, SP, Brazil) with simple stitches.

The BFPG was placed into the recipient site at the level of the CEJ, and fixed by X-shaped sutures over the graft (Fig. 2B) with absorbable suture thread (Vicryl 5-0). The same trans-surgical measurements performed in the control group were also performed in the test group. The heights of the grafts ranged from 7.7 to $10.3 \mathrm{~mm}$. The flap was coronally positioned in order to cover the entire BFPG. Suspensory and simple sutures were made in the releasing incisions (Fig. 2C). After the sutures were finished, the CPF-AG was measured.

\section{Postoperative Protocol}

The patients were given postoperative instructions, including ice compression on the surgical site during the first $4 h$, a liquid and/or soft food diet for 3 days, no brushing of the teeth in the surgical region, mouth rinsing with a mouthwash containing $0.12 \%$ chlorhexidine digluconate for $1 \mathrm{~min}$ every $12 \mathrm{~h}$ for 14 days. The postoperative medications prescribed were amoxicillin $500 \mathrm{mg}$ every 8 $\mathrm{h}$ for 7 days or clindamycin $300 \mathrm{~g}$ every $8 \mathrm{~h}$ for 7 days for patients allergic to penicillin, and ibuprofen + arginine $600 \mathrm{mg}$ every $12 \mathrm{~h}$ for 5 days. The sutures were removed 14 days after surgery. After this period, the patients were instructed to brush their teeth gently, with a soft-bristled toothbrush. All patients participated in a monthly program of professional tooth cleaning and oral hygiene instruction, from the $30^{\text {th }}$ day to the $180^{\text {th }}$ day after the surgery.
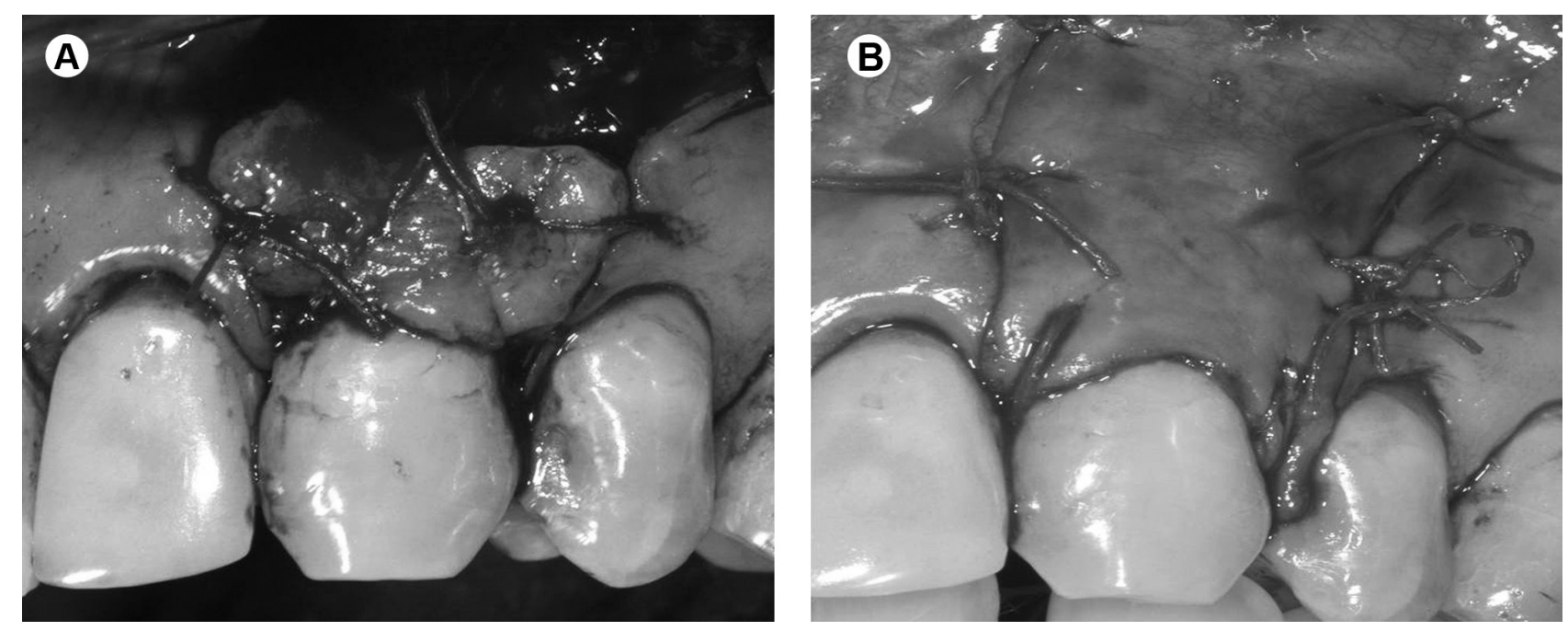

Figure 1. SCTG group. A: Connective tissue graft sutured over the recipient site. B: Flap positioned coronally and sutured. 


\section{Statistical Analysis}

Repeated measures analysis of variance along with the Bonferroni method was used to detect inter-group and intra-group differences for the clinical parameters PD, GR, CAL, WKT, TKT and GM-AG. The $t$-test was used to assess inter-group differences versus time for the clinical parameters PD, GR, CAL, WKT, TKT and GM-AG. For the parameters $\mathrm{CPRS}-\mathrm{AG}, \mathrm{CPG}-\mathrm{AG}, \mathrm{ACHG}$ and $\mathrm{CPF}-\mathrm{AG}$, only the $t$-test was used. For all statistical comparisons, $\mathrm{p}<0.05$ was set to indicate statistical significance. SPSS Statistics 18 software was used to perform all analyses.

\section{Results}

Both groups had similar GR sizes at baseline; there was
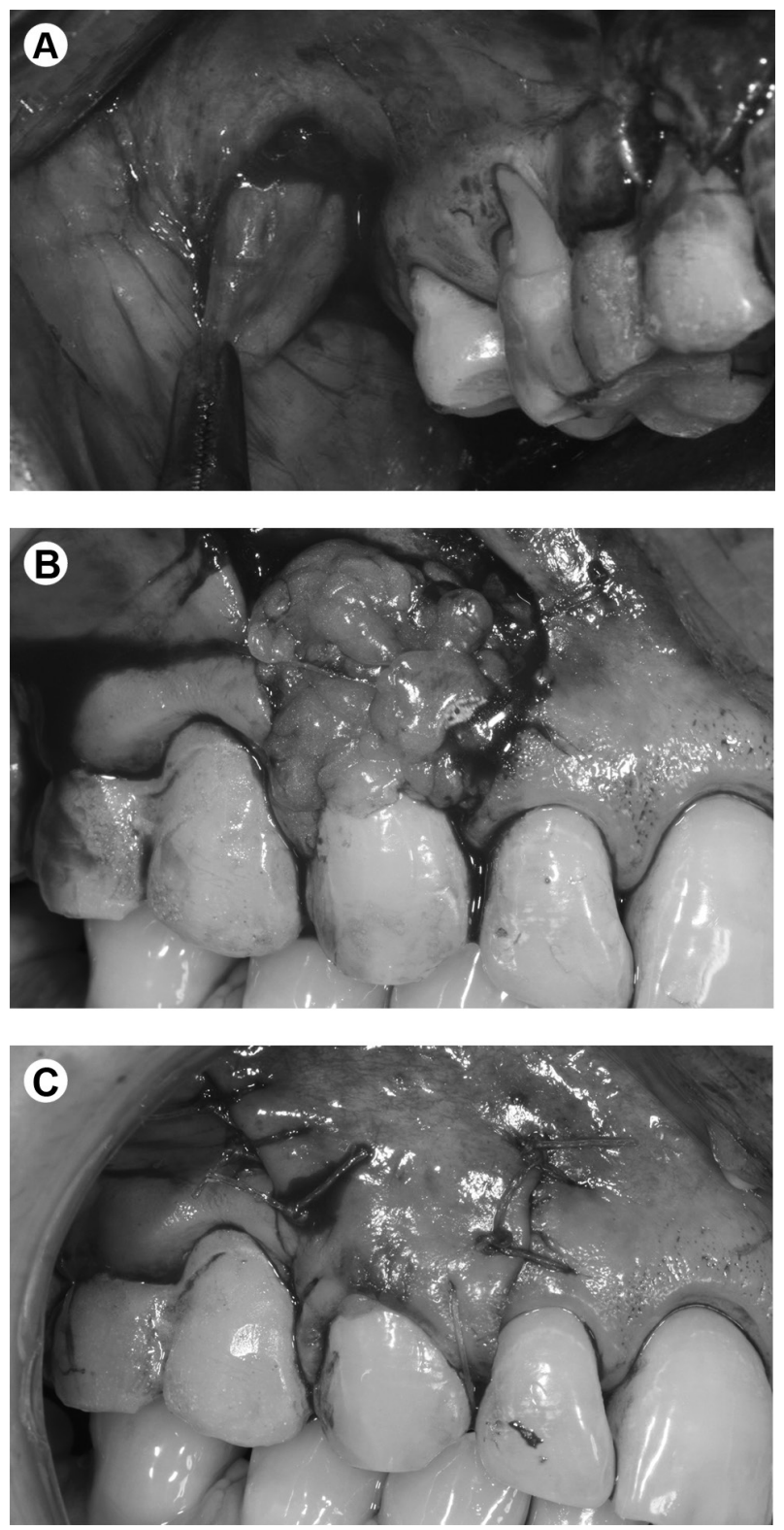

Figure 2. BFPG group. A: Removal of buccal fat pad. B: BFPG sutured over the recipient site. C: Flap positioned coronally and sutured. no statistically significant difference between the groups (group C: $3.25 \pm 1.14 \mathrm{~mm}$; group T: $3.46 \pm 1.03 \mathrm{~mm}$ ) (Table 1). There were no postoperative healing complications, and no patient was excluded from the study after enrolment. With regard to clinical results, partial root coverage was observed 1 month after surgery and the patients reported absence of dentin hypersensitivity in both their treated teeth (groups $\mathrm{C}$ and T). The side treated with BFPG exhibited redder and brighter gingival tissue than the side treated with SCTG only 1 month after surgery. Both groups exhibited similar clinical healing at the other assessed postoperative timepoints (Figs. 3A-3F). The $\mathrm{Gl}$ was 0 and the PI score was 1 in both groups throughout the patients' postoperative follow-up (1, 3 and 6 months).

The analyses of preoperative and postoperative clinical parameters in both groups are shown in Table 1. None of the evaluated clinical parameters differed significantly between the groups at baseline or at any of the assessed

Table 1. Clinical parameters ( $\mathrm{mm}$; mean \pm standard deviation) at baseline and 1,3, and 6 months postoperatively

\begin{tabular}{|c|c|c|}
\hline $\begin{array}{l}\text { Clinical } \\
\text { parameter }\end{array}$ & $\begin{array}{c}\text { Group T } \\
\text { (BFPG) }\end{array}$ & $\begin{array}{c}\text { Group C } \\
\text { (SCTG) }\end{array}$ \\
\hline \multicolumn{3}{|l|}{ PD } \\
\hline Baseline & $1.33 \pm 0.49$ & $1.25 \pm 0.45$ \\
\hline 1 month & $1.88 \pm 0.80$ & $2.00 \pm 0.71^{*}$ \\
\hline 3 months & $1.42 \pm 0.63$ & $1.63 \pm 0.61$ \\
\hline 6 months & $1.50 \pm 0.64$ & $1.67 \pm 0.62$ \\
\hline \multicolumn{3}{|l|}{ GR } \\
\hline Baseline & $3.46 \pm 1.03$ & $3.25 \pm 1.14$ \\
\hline 1 month & $1.08 \pm 1.24 *$ & $1.00 \pm 1.28 *$ \\
\hline 3 months & $1.25 \pm 1.60 *$ & $0.92 \pm 1.38 *$ \\
\hline 6 months & $1.25 \pm 1.48 *$ & $1.08 \pm 1.38 *$ \\
\hline \multicolumn{3}{|l|}{ CAL } \\
\hline Baseline & $4.67 \pm 1.07$ & $4.63 \pm 1.19$ \\
\hline 1 month & $2.96 \pm 1.39 *$ & $3.00 \pm 1.43$ \\
\hline 3 months & $2.67 \pm 1.48 *$ & $2.54 \pm 1.21 *$ \\
\hline 6 months & $2.75 \pm 1.34 *$ & $2.83 \pm 1.54 *$ \\
\hline \multicolumn{3}{|l|}{ WKT } \\
\hline Baseline & $3.50 \pm 1.24$ & $3.67 \pm 1.61$ \\
\hline 1 month & $5.25 \pm 1.14 *$ & $5.50 \pm 1.38$ \\
\hline 3 months & $4.67 \pm 0.89$ & $5.17 \pm 1.47$ \\
\hline 6 months & $5.08 \pm 1.24$ & $5.42 \pm 1.56$ \\
\hline \multicolumn{3}{|l|}{ TKT } \\
\hline Baseline & $1.08 \pm 0.29$ & $1.08 \pm 0.29$ \\
\hline 1 month & $1.46 \pm 0.40$ & $1.79 \pm 0.58 *$ \\
\hline 3 months & $1.50 \pm 0.43$ & $1.84 \pm 0.44 *$ \\
\hline 6 months & $1.46 \pm 0.45$ & $1.67 \pm 0.65$ \\
\hline \multicolumn{3}{|l|}{$\mathrm{GM}-\mathrm{AG}$} \\
\hline Baseline & $6.92 \pm 1.88$ & $6.92 \pm 1.56$ \\
\hline 1 month & $4.79 \pm 1.92 *$ & $4.42 \pm 1.73 *$ \\
\hline 3 months & $4.88 \pm 2.05 *$ & $4.33 \pm 1.78 *$ \\
\hline 6 months & $4.88 \pm 1.96 *$ & $4.50 \pm 1.78 *$ \\
\hline
\end{tabular}

$\mathrm{PD}=$ probing depth $\mathrm{GR}=$ gingival recession $; \mathrm{CAL}=$ clinical attachment level; WKT = width of keratinized tissue; TKT = thickness of keratinized tissue; $\mathrm{GM}-\mathrm{AG}$ = gingival margin to the acrylic guide. *Statistically significant difference compared with baseline, intra-group comparison $(\mathrm{p}<0.05)$. 
postoperative periods. Both groups showed statistically significant differences in GR and GM-AG at 1, 3 and 6 months postoperatively in comparison with baseline. With regard to $C A L$, group $C$ differed significantly from baseline at 3 and 6 months postoperatively, while group T differed significantly from baseline at all assessed postoperative periods, 1, 3 and 6 months.

The measures performed during the trans-surgical procedures are shown in Table 2. There was a statistically significant difference in ACHG between the groups. The
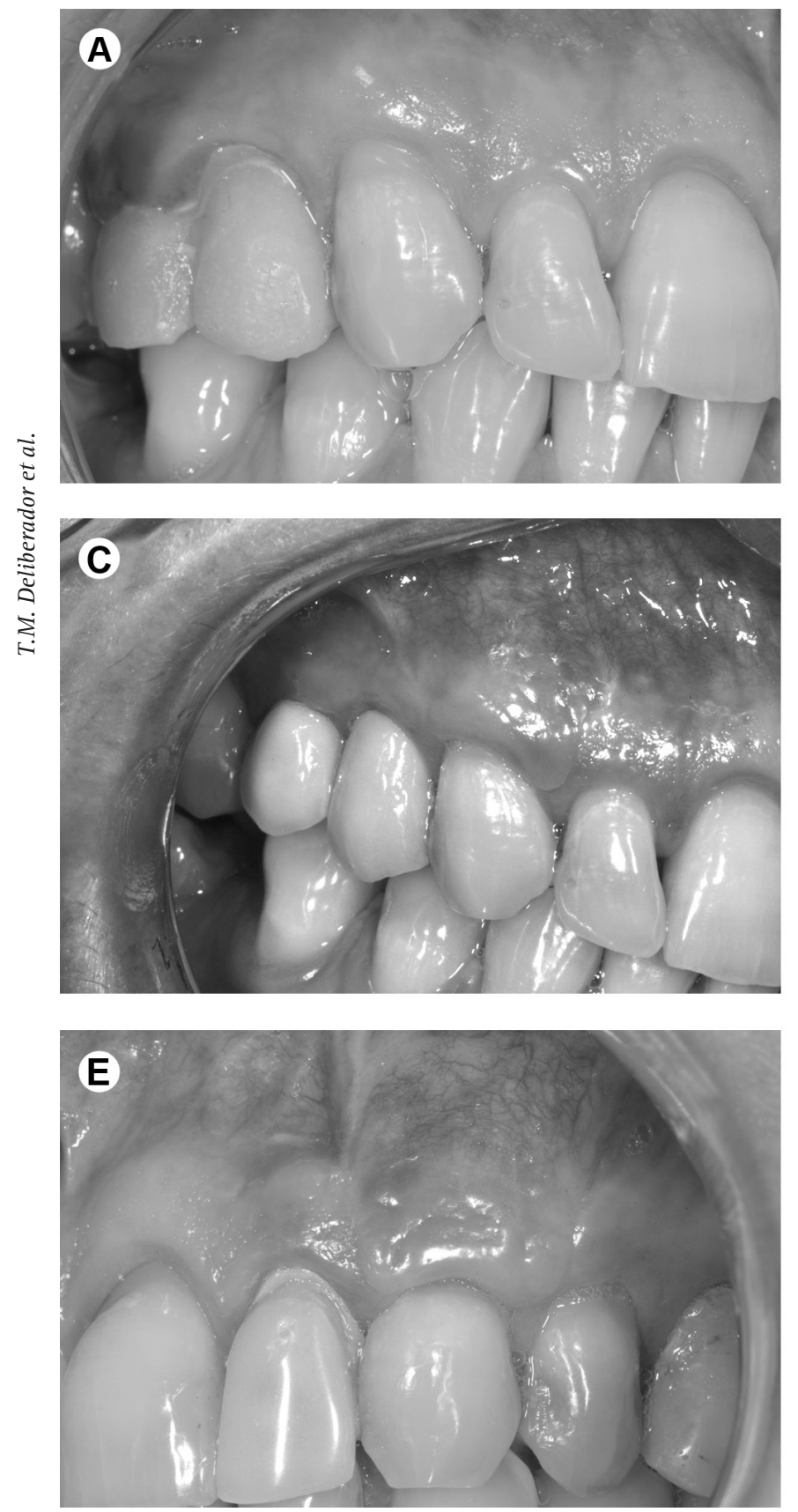

mean root coverage values for both groups 6 months after surgery are shown in Table 3 . The mean percentage of root coverage was $87.5 \%$ for group $\mathrm{C}$ and $67.5 \%$ for group $\mathrm{T}$. Complete root coverage was evident in $50 \%$ of cases ( 6 out of 12) in both group $C$ and group $T 6$ months after surgery.

\section{Discussion}

The aim of this randomized controlled split-mouth clinical trial was to compare non-pedicled BFPG with SCTG for the treatment of Miller Class I or Class II GRs. This is
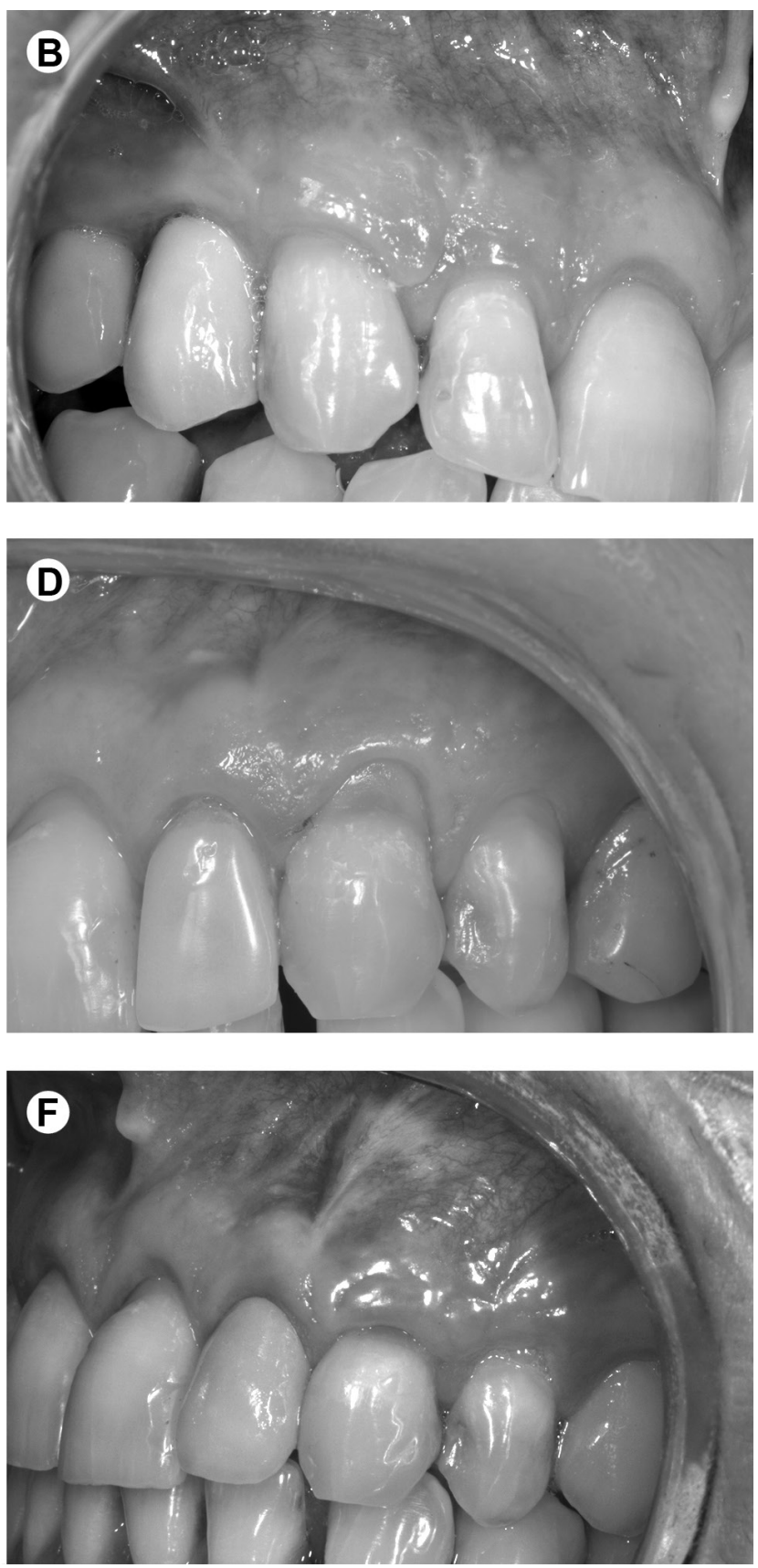

Figure 3. A: BFPG group. Maxillary right canine with Miller Class 1 gingival recession at baseline. B: BFPG group 3 months after surgery. C: BFPG group 6 months after surgery. D: SCTG group. Maxillary left canine with Miller Class 1 gingival recession at baseline. E: SCTG group 3 months after surgery. F: SCTG group 6 months after surgery. 
the first randomized controlled clinical trial to evaluate buccal fat pad as a grafting alternative for the treatment of GRs, more specifically minor GRs (the Miller Class I and II recessions) in esthetic area. The use of buccal fat tissue as a grafting alternative has recently been outlined in case-reports describing the use of pedicled BFPG in the treatment of Miller Class IV $(6,11)$ and Class III $(7)$ GRs. In both cases excellent cosmetic results were reported. It has also been reported that BFPG is easy to harvest, the process is versatile and simple, and associated with relatively low morbidity at the donor site, the rate of postoperative complications is low and the surgical technique is fast (6).

The adipose tissue derived from the Bichat's ball was also used in this study. However, non-pedicled buccal fat tissue was utilized, the rationale being that it represented a possibly autogenous alternative to a SCTG. The Bichat's ball has long been used in dentistry for oral reconstructions (8).

The use of BFPG and adipose tissue-derived stem cells (ADSCs) has been the focus of both in vitro (12) and in vivo $(13,14)$ studies. ADSCs have become the most popular type of adult stem cells for studies in the fields of soft tissue engineering and regenerative medicine. Compared with stem cells from other sources, ADSCs offer some advantages because they are not only abundant, autologous, and characterized by less invasive harvesting procedures and lower morbidity, they are also a multipotent cell lineage with significant proliferative capacity in culture (15). Recently it was reported that the non-fat fraction of adipose tissue is also rich in endothelial and progenitor cells, which represent a rich and abundant source of osteogenic and vasculogenic cells (16).

Due to recent advances in ADSC research, the use of adipose tissue as a grafting alternative has not been evaluated in vivo, either as a treatment option for periodontal and bone regeneration or for the treatment of reconstructive esthetic problems such as GRs. To the best of our knowledge, the present study is the first randomized controlled clinical trial to evaluate buccal fat pad as a

Table 2. Trans-surgical measures (mm; mean \pm standard deviation)

\begin{tabular}{lcc}
\hline $\begin{array}{l}\text { Trans-surgical } \\
\text { Measure }\end{array}$ & $\begin{array}{c}\text { Group T } \\
\text { (BFPG) }\end{array}$ & $\begin{array}{c}\text { Group C } \\
\text { (SCTG) }\end{array}$ \\
\hline CPRS-AG & $9.50 \pm 2.20$ & $9.00 \pm 2.10$ \\
CPG-AG & $6.10 \pm 2.60$ & $5.80 \pm 1.90$ \\
ACHG & $9.00 \pm 1.30^{*}$ & $7.70 \pm 1.20^{*}$ \\
CPF-AG & $6.10 \pm 2.60$ & $5.80 \pm 1.90$ \\
\hline
\end{tabular}

CPRS-AG = most coronal portion of the recipient site to the acrylic guide; $\mathrm{CPG}-\mathrm{AG}=$ most coronal portion of the graft to the acrylic guide; $\mathrm{ACHG}=$ apico-coronal height of the graft; $\mathrm{CPF}-\mathrm{AG}=$ the most coronal position of the flap to the acrylic guide. *Statistically significant difference, inter-group comparison $(t$-test, $\mathrm{p}<0.05)$. grafting alternative, i.e., a new autogenous option for the treatment of GRs.

Gingival tissue gain, not only in thickness but also in width, represents a desirable and advantageous effect after the treatment of GRs with SCTG, which reduces the possibility of an eventual recurrence. The thinner the gingival tissue, the more susceptible it is to injuries caused by hard brushing trauma or chronic inflammation. In the present study, only the SCTG group exhibited an increase in keratinized tissue thickness in the $1^{\text {st }}$ and $3^{\text {rd }}$ postoperative months, with a statistically significant difference compared to baseline. There was no statistically significant difference 6 months after surgery; in fact, numerical values were very similar. Thus, SCTG may be advantageous over BFPG in terms of root coverage maintenance in the long term. This study only evaluated the results up to 6 months after surgery. Therefore, further evaluation is required in order to assess the effectiveness and stability of this new surgical technique over longer periods. According to Bittencourt et al. (17), the SCTG is a highly stable technique in the long term.

With regard to the width of keratinized tissue, only the BFPG group exhibited a significant width increase 1 month after surgery (Table 1). At the other evaluated postoperative time-points (3 and 6 months), the width of keratinized tissue did not differ significantly in comparison to baseline. This initial gain in width can be explained by the fact that buccal fat pad is an organized type of tissue, which, unlike subcutaneous fat, is not subject to lipid metabolism. Buccal fat pad has different lipolysis kinetics and retains the volume

Table 3. Percentage of root coverage 6 months after surgery compared to baseline

\begin{tabular}{ccc}
\hline Patient & $\begin{array}{c}\text { Test Group } \\
\text { (BFPG) }\end{array}$ & $\begin{array}{c}\text { Control Group } \\
\text { (SCTG) }\end{array}$ \\
\hline 1 & 0 & 33 \\
2 & 0 & 50 \\
3 & 33 & 50 \\
4 & 100 & 100 \\
5 & 100 & 100 \\
6 & 100 & 100 \\
7 & 0 & 33 \\
8 & 100 & 100 \\
9 & 100 & 100 \\
10 & 66 & 66 \\
11 & 100 & 100 \\
12 & 75 & 33 \\
Mean \pm SD & $67.50 \pm 47.21$ & $87.50 \pm 23.15$ \\
\hline
\end{tabular}


of its structure for a certain time (18).

Both techniques investigated in the present study yielded good mean percentages of root coverage 6 months after surgery. This outcome agrees with previous studies $(19,20)$ involving SCTG, which reported mean percentages of root coverage ranging from $60 \%$ to $98.9 \%$. Complete root coverage was observed in 50\% of the cases in both groups of the present study 6 months after surgery. This rate was lower than the one reported in other controlled clinical trials (17) which also used SCTG to treat GRs. Such variation in results is commonplace and may be due to various factors including the clinical experience of the surgeons, periodontal biotype, the healing potentials of the patients in the studies and the anatomical characteristics of their GRs (21).

Owing to the lack of studies involving the relatively new technique of BFPG, it was not possible to compare the results from the BFPG group with those of other studies. However, GRs treated via BFPG exhibited the same frequency of complete root coverage as those treated via SCTG, which is considered the gold standard for the treatment of GRs (22). Therefore, the use of BFPG can be considered a predictable treatment option for Miller class I and II GRs, because the same frequency of complete root coverage was achieved in comparison to SCTG.

In terms of clinical efficacy, both groups in the present study exhibited satisfactory cosmetic results, without significant differences in healing. In this study, there were no statistically significant differences in the main clinical parameters evaluated between the groups. Both groups exhibited clinical attachment gain and PD stability 1, 3, and 6 months postoperatively. While this study only evaluated single GRs, the BFPG can also be used to treat extensive multiple recessions. This is a great advantage, as this type of tissue is abundant and the technique is clinically viable. Moreover, for being totally autogenous, non-pedicled buccal fat pad can also be used in the treatment of single or multiple GRs either far from the donor site or in the opposite arch.

Similarly, the SCTG is a very predictable technique associated with high rates of root coverage $(4,17)$. However, one of the major disadvantages of this technique is the necessity of harvesting soft tissue from the palate, causing pain and discomfort to patients (23). The majority of the patients in the present study stated that the postoperative pain in the donor site that provided BFPG was less acute than the pain in the donor site that provided SCTG. Therefore, in addition to being simpler, easier and faster, the BFPG technique is also characterized by lower morbidity at the donor site than the SCTG technique. These results agree with those reported by El Haddad et al. (6). Nevertheless, most patients had facial edema, which caused a type of "esthetic discomfort." This is the main disadvantage of the BFPG technique for treatment of GRs.

In this study, trans-surgical measures were performed in order to achieve the maximum possible standardization of all surgical procedures in both groups. There were no statistically significant differences in the CPRS-AG, CPG$A G$, or CPF-AG between the groups. The BFPG group differed significantly from the SCTG group with regard to $\mathrm{ACHG}$, i.e., a larger amount of BFPG was used. This is justifiable because adipose tissue is a shapeless type of tissue. It is not possible to make a map or guide to ensure the removed graft is always of the same shape and size. However, this fact did not influence the results because there were no significant differences in the main clinical parameters evaluated between the groups (Table 1).

The outcomes of this study indicate that the use of BFPG transplant has clinical similarities with SCTG and both may be considered as clinically successful methods for treating Miller Class I and II GRs. However, the findings of this study also demonstrate the need for further randomized controlled clinical trials, in order to confirm the effectiveness of this new graft option for the treatment of GRs in the long term.

\section{Resumo}

0 objetivo deste estudo foi analisar a eficiência do transplante do enxerto de tecido adiposo bucal não pediculado (ETAB) para o tratamento de recessões gengivais Classe I e II de Miller e comparar seus resultados com o enxerto de tecido conjuntivo (ETC), que é considerado o enxerto padrão ouro. Foram selecionados 12 pacientes com recessões gengivais bilaterais Classe I e II de Miller presentes em canino ou pré-molares maxilares. As recessões foram randomizadas para receber um dos dois tratamentos ETAB ou ETC. Os parâmetros clínicos avaliados no baseline e com 1, 3 e 6 meses de pós-operatório foram o índice gengival, índice de placa, profundidade de sondagem, recessão gengival (RG), nível clinico de inserção, espessura e largura de tecido queratinizado e a medida da margem gengival ao guia de acrílico (MG-GA). Os resultados mostraram que não houve diferença estatisticamente significativa entre os grupos em nenhum dos parâmetros clínicos avaliados. Os parâmetros clínicos de RG e MG-GA, em ambos os grupos, apresentaram diferença estatisticamente significativa nos 3 períodos pós-operatórios em relação ao baseline. Aos 6 meses de pós-operatório, a média percentual de recobrimento radicular foi de $67,5 \%$ e $87,5 \%$ para o grupo ETAB e ETC respectivamente. Em ambos os grupos o recobrimento radicular completo foi em $50 \%$ dos casos após 6 meses de pós-operatório. Pode-se concluir que o transplante do ETAB apresentou similaridades clínicas com o ETC e ambos os tratamentos podem ser considerados de sucesso clínico para o tratamento de RGs Classe I e II de Miller.

\section{References}

1. Goldstein M, Nasatzky E, Goultschin J, Boyan BD, Schwartz Z. Coverage of previously carious roots is a predictable a procedure of intact roots. J Periodontol 2002;73:1419-1426.

2. Lucchesi JA, Santos VR, Amaral CM, Peruzzo DC, Duarte, PM. Coronally positioned flap for treatment of restored root surfaces: a 6-month clinical evaluation. J Periodontol 2007;78:615-623.

3. Cairo $F$, Nieri M, Pagliaro U. Efficacy of periodontal plastic surgery procedures in the treatment of localized facial gingival recessions. A systematic review. J Clin Periodontol 2014;41 Suppl 15:S44-s62. 
4. de Sanctis M, Baldini N, Goracci C, Zucchelli G. Coronally advanced flap associated with a connective tissue graft for the treatment of multiple recession defects in mandibular posterior teeth. Int J Periodontics Restorative Dent 2011;31:623-630.

5. McGuire MK, Scheyer ET, Snyder MB. Evaluation of recession defects treated with coronally advanced flaps and either recombinant human platelet-derived growth factor-BB plus $\beta$-tricalcium phosphate or connective tissue: comparison of clinical parameters at 5 years. $J$ Periodontol 2014:85:1361-1370.

6. El Haddad AS, Abd El Razzak MY, El Razzak MY, El Shall M. Use of pedicled buccal fat pad in root coverage of severe gingival recession defect. J Periodontol 2008;79:1271-1279.

7. Kumari CBN, Thiagarajan $R$, Narayanan $V$, Devadoss $P$, Mammen $B$, Emmadi P. A new technique for root coverage using buccal fat pad - $A$ short case report. Quint International 2010;41:547-549.

8. Toshihiro $Y$, Nariai $Y$, Takamura $Y$, Yoshimura $H$, Tobita $T$, Yoshino A, et al. Applicability of buccal fat pad grafting for oral reconstruction. Int J Oral Maxillofac Surg 2013;42:604-610.

9. Löe $H$. The gingival index, the plaque index and the retention index systems. J Periodontol 1967;38:Suppl:610-616.

10. Silness $J$ and Löe H. Periodontal disease in pregnancy II. Correlation between oral hygiene and periodontal condition. Acta Odontol Scand 1964;22:121-135.

11. Agarwal C, Gayathri GV, Mehta DS. An innovative technique for root coverage using pedicled buccal fat pad. Contemp Clin Dent 2014;5:386-388.

12. Wang $\mathrm{Q}$, Steigelman MB, Walker JA, Chen S, Hornsby PJ, Bohnenblust $M E$, et al.. In vitro osteogenic differentiation of adipose stem cells after lentiviral transduction with green fluorescent protein. J Craniofac Surg 2009:20:2193-2199.

13. Zou J, Wang G, Geng D, Zhu X, Gan M, Yang H. A novel cell-based therapy in segmental bone defect: using adipose derived stromal cells. J Surg Res 2011;168:76-81.

14. Deliberador TM, Giovanini AF, Lopes TR, Zielak JC, Moro A, Baratto Filho $F$, et al.. Immunoexpression of PPAR- $\gamma$ and osteocalcin proteins for bone repair of critical-size defects treated with fragmented autogenous abdominal adipose tissue graft. Braz Dent J 2014:25:179185.

15. Philips BJ, Marra KG, Rubin JP. Adipose stem cell-based soft tissue regeneration. Expert Opin Biol Ther 2012;12:155-163.

16. Scherberich A, Müller AM, Schäfer DJ, Banfi A, Martin I. Adipose tissuederived progenitors for engineering osteogenic and vasculogenic grafts. J Cell Physiol 2010;225:348-353.

17. Bittencourt $\mathrm{S}$, Ribeiro EDP, Sallum EA, Sallum AW, Nociti Jr FH, Casati MZ. Semilunar coronally positioned flap or subepithelial connective tissue graft for the treatment of gingival recession: a 30-month follow-up study. J Periodontol 2009;80:1076-1082.

18. Zhong L, Chen G, Fan L, Zhao SF. Immediate reconstruction of maxilla with bone grafts supported by pedicled buccal fat pad graft. Oral Surg Oral Med Oral Pathol Oral Radiol Endod 2004;97:147-154.

19. Nelson SW. The subpedicle connective tissue graft. A bilaminar reconstructive procedure for the coverage of denuded root surfaces. Journal of Periodontology 1987;58:95-102.

20. Harris RJ. Root coverage with connective tissue grafts: an evaluation of short- and long-term results. J Periodontol 2002;73:1054-1059.

21. Cortellini P, Pini Prato G. Coronally advanced flap and combination therapy for root coverage. Clinical strategies based on scientific evidence and clinical experience. Periodontol 2000 2012;59:158-184.

22. Zucchelli G, Mounssif I, Mazzotti C, Stefanini M, Marzadori M, Petracci $\mathrm{E}$, et al.. Coronally advanced flap with and without connective tissue graft for the treatment of multiple gingival recessions: a comparative short- and long-term controlled randomized clinical trial. J Clin Periodontol 2014:41:396-403.

23. Griffin TJ, Cheung WS, Zavras Al, Damoulis PD. Postoperative complications following gingival augmentation procedures. J Periodontol 2006;77:2070-2079.
Received August 13, 2015 Accepted November 8, 2015 